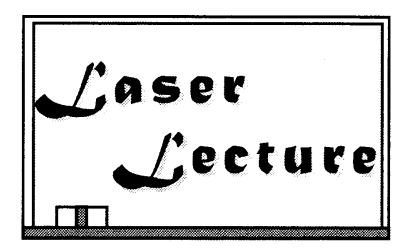

\author{
半導体レーザーの基礎II \\ 須崎 渉 \\ 大阪電気通信大学 ( $572-8530$ 寝屋川市初町18-8)
}

\title{
Fundamentals of Semiconductor Lasers II
}

Wataru SUSAKI

Osaka Electro-Communication University, 18-8 Hatsu-Cho, Neyagawa 572-8530

(Received July 30, 2001)

\section{5. 発振モードの制御と素子構造}

\section{1 半導体レーザーの発振モード}

半導体レーザーの横モードについてはホモ接合の時代 に遡る。ヘキ開面による反射鏡と垂直な金属ストライプ 電極により電流の注入幅を制限すると,横モードが観測さ れたのが最初である17)。電流によるキャリヤの注入領域 をストライプ状に制限するものをストライプ構造と言い, 最初の構造は電極ストライプ構造と呼ばれる.

ダブルヘテロ接合による室温連続発振達成後の大きな

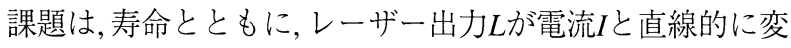
化せずキンクを生じることであった。これは, 応用上大き な問題となった。この問題は横モードに起因し,電流を増 加させていくと次々に低次モードから高次モードに移動 し，その度にモード競合によるキンクを生じていることが 明らかにされた18). 基本横モードのみで安定に発振させ るにはストライプ幅を狭くする必要がある．当時の加工

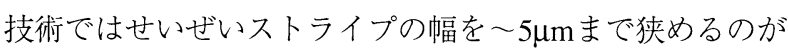
精一杯であった．Fig.5.1は横モードの競合によるキンクを 模式的に示す。

このL-I特性に現れるキンクの問題は, 活性層の幅 $2 \mu \mathrm{m}$ の基本横モードでのみで発振するTJS型レーザーの出現に より解決され, 最初の“キンクフリー”レーザーとなっ た ${ }^{19,20)}$.このレーザーは, Fig.5.2に示すように, ダブルへテ ロ構造のへテロ接合と垂直にホモ接合の $\mathrm{p}^{+} \mathrm{pn} 3$ 層構造を形 成したもので,まずZnの拡散によって $\mathrm{p}^{+} \mathrm{n}$ 構造を形成し，そ の後に高温アニールによる押し出し拡散により $\mathrm{p}^{+} \mathrm{pn}$ 構造を 形成し,キャリヤ注入による再結合発光を生じる中央の活 性領域p層の幅を〜 $2 \mu \mathrm{m}$ と狭めた結果である.

この基本横モードのみで発振するTJSレーザーでは定常 状態の直流動作では, 単一波長スペクトルで発振すること が初めて明らかにされた。すなわち縦モードは単一モー ドで発振した．従来のレーザーは多数の縦モードで発振 していたが,これは複数の横モードが混在する結果である

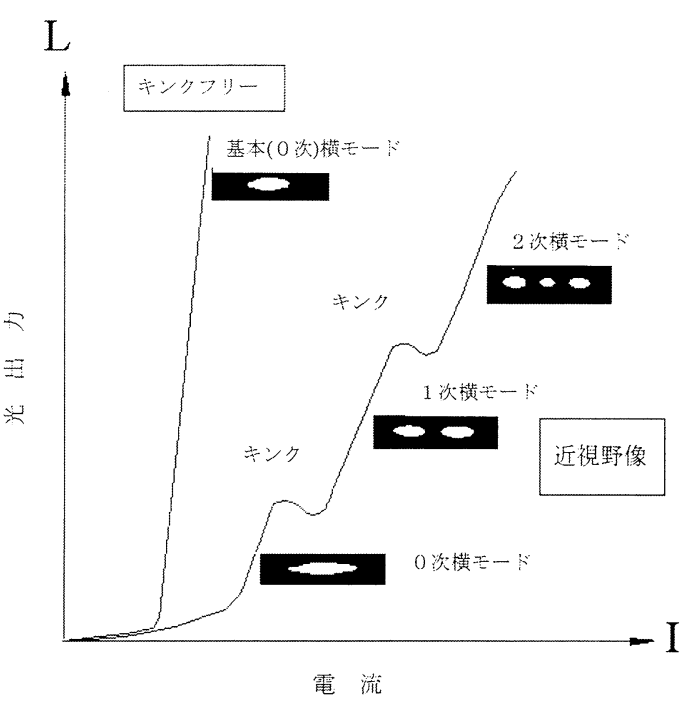

Fig.5.1 Kinks in light output - current (L - I) characteritics.
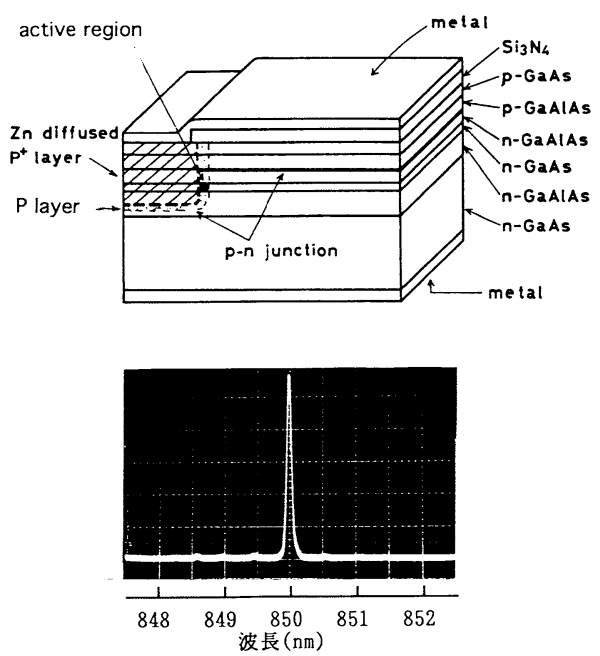

Fig.5.2 The first single mode semiconductor laser operating with a fundamental transverse and longitudinal mode: TJS laser. 


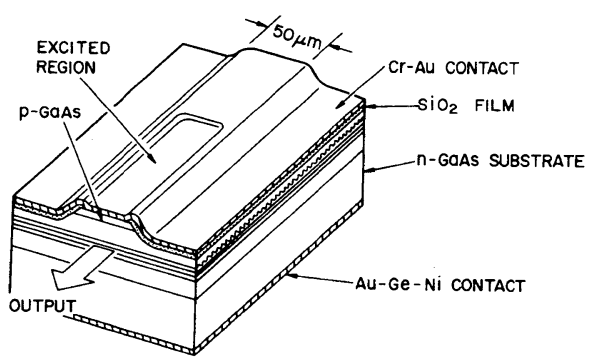

Fig.5.3 The first AlGaAs DFB laser.

と認識されるようになった.TJSレーザーに続いて, 各種 の基本横モードで発振するレーザーが開発されている。

しかし, 直流動作では縦モードが単一となったといって も, 交流信号を重畳すると, 縦モードは単一ではなくなり, 多モードで発振することが分かった。これはへキ開面を 利用したファブリ・ペロー型の共振器では縦モード間の 発振利得差が小さいためである。交流の重畳により縦 モードが多モードとなることは,コンパクトディスクなど への応用には雑音を軽減できる方法として利用されるよ うになるが,光ファイバ通信では光ファイバの波長により 屈折率が変化するために生じる材料分散や導波路分散に より，伝送带域が制限されるなどの問題が生じる。このた め, 電流による変調によっても, 縦モードが単一であるこ とが要求される。この様な素子として,レーザー共振器に 回折格子を活性領域に沿って形成する分布帰還型素子が 現れた21). Fig.5.3は最初の素子である。この分布帰還型素 子は,横モードが基本モードで発振する構造に適用され, 今 日の光通信用光源である波長 $1.3,1.55 \mu \mathrm{m}$ で使われる $\mathrm{InP}$ 基板とするInGaAsPレーザーで5.3に述べる動的単一モード レーザー22)として発展する。

\section{2 横モード制御と基本横モード発振レーザー}

\section{2 .1 ダブルヘテロ構造光導波路}

ここではまずへテロ接合と垂直な方向の横モードを取 り扱う.ダブルヘテロ構造では中央の光導波路層はこれ をサンドイッチ上に挟むクラッド層にくらべ屈折率が少 し大きい.ダブルヘテロ構造の活性層はそれを挟むク ラッド層に比ベバンドギャップが小さくかつ偶然で幸い なことに屈折率が大きくなっている．Fig.5.4はAlGaAsの 屈折率の波長依存性を示す23).

Fig.5.5はダブルへテロ構造による光導波路の断面図であ り,へテロ接合と垂直, および平行な方向をそれぞれ $x$ 軸, $y$ 軸, 光波の進行方向を $z$ 軸に選ぶ. 各層の屈折率は, コアで は $n_{1}$, クラッド層では $n_{2}$ とし, 層厚は活性導波路では $d$, ク ラッド層では十分大きくめと近似できる場合を考える。 $n_{1}$ $>n_{2}$ の場合に光の入射角が次式で与えられる場合に活性導 波路内に閉じ込めて導波することができる.

$$
\theta \leq \sin ^{-1}\left(n_{2} / n_{1}\right)
$$

この式は導波光伝播の必要条件であるが,十分条件ではな い. 導波可能な光波は伝播方向と垂直な成分が定在波を 形成するので, 以下に示すように, 導波可能な伝播角はと びとびの值をとる。この值は, 波長と導波路の構造によっ

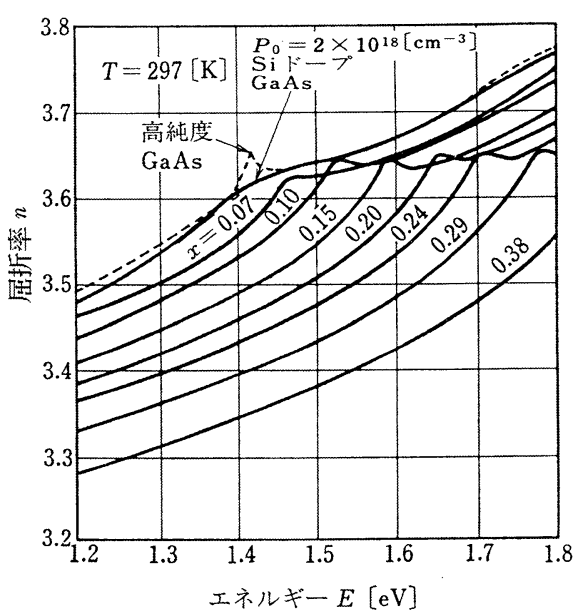

Fig.5.4 Refractive indices of $\mathrm{Al}_{\mathrm{x}} \mathrm{Ga}_{1-\mathrm{x}} \mathrm{As}$.

て決まる。このような光波の伝播・導波の形態を導波 モードと言う.

光の電界 $\boldsymbol{E}$ と磁界 $\boldsymbol{H}$ は, 時間に対する依存性を exp (-jwt) であるとすると,マクスウエルの方程式より次式が成り立 つ.

$$
\begin{aligned}
& \nabla \times \boldsymbol{E}=-j \omega \mu_{0} \boldsymbol{H} \\
& \nabla \times \boldsymbol{H}=j \omega \varepsilon \boldsymbol{E}
\end{aligned}
$$

$\mu_{0}$ は真空の透磁率, $\varepsilon$ は媒質の誘電率である.

(5.2)，(5.3) 式から磁界Hを消去すると,

$$
\nabla \times \nabla \times \boldsymbol{E}=\nabla(\nabla \cdot \boldsymbol{E})-\nabla^{2} \boldsymbol{E}=\omega^{2} \varepsilon \mu_{0} \boldsymbol{E}
$$

通常媒質は電気的に中性で電荷密度 $\rho=0$ と置くことがで き, $\nabla \cdot \boldsymbol{E}=\rho / \varepsilon=0$ であり，(5.4) 式は次のようになる.

$$
\nabla^{2} \boldsymbol{E}+\omega^{2} \varepsilon \mu_{0} \boldsymbol{E}=0
$$
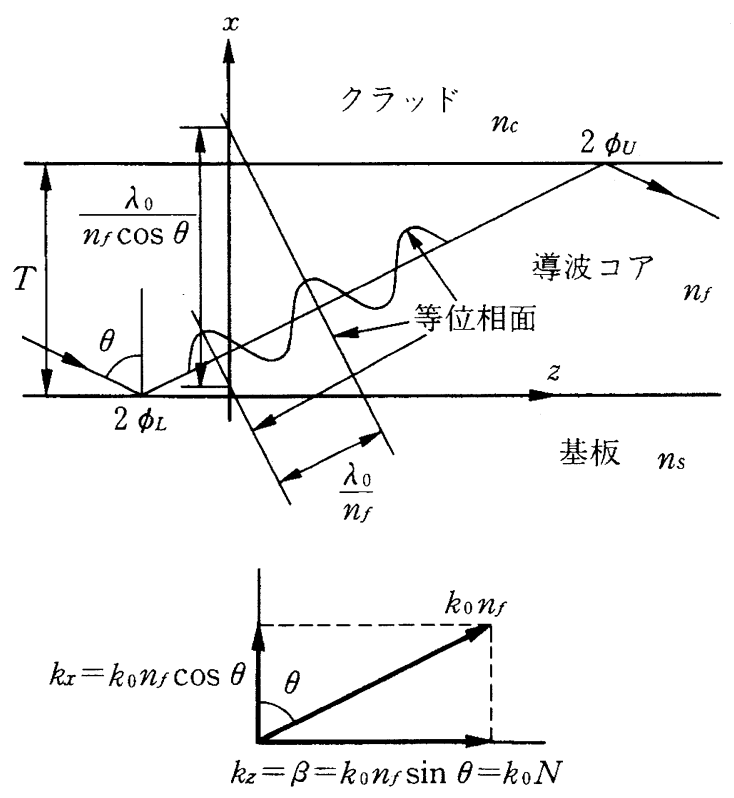

Fig.5.5 Propagation of light in a symmetric three layer slab dielectric waveguide. 
同様にしてEを消去するとHについても次式が成り立つ.

$$
\nabla^{2} \boldsymbol{H}+\omega^{2} \varepsilon \mu_{0} \boldsymbol{H}=0
$$

これらの式より電界および磁界の成分 $E_{\mathrm{x}}, E_{\mathrm{y}}, E_{\mathrm{z}}$ および $H_{\mathrm{x}}$, $H_{\mathrm{y}}, H_{\mathrm{z}}$ をфで表すと, $\phi$ は次の波動方程式で与えられる.

$$
\left(\frac{\partial^{2}}{\partial x^{2}}+\frac{\partial^{2}}{\partial y^{2}}+\frac{\partial^{2}}{\partial z^{2}}\right) \phi+\omega^{2} \mu_{0} \varepsilon \phi=0
$$

ここではy方向には無限の平板であると近似することに より, $\partial / \partial y=0$ が成り立つ。任意の導波モードは電界ある いは磁界がy方向に平行な成分のみで表されるTEモードと TMモードに分離できる，半導体レーザーでは,レーザー光 の進行方向と垂直でへテロ接合と平行な方向にのみに電 界をもつTEモードと, 同じくへテロ接合と平行な方向にの みに磁界をもつTMモードが観測されている。このTEモー ドとTMモードは伝播速度や群速度は僅かではあるが互い に違っている。TEモードとTMモードの成分は

TEモード : $E\left(0, E_{y}, 0\right), H\left(H_{x}, 0, H_{z}\right)$

TMモード : $H\left(0, H_{y}, 0\right), E\left(E_{x}, 0, E_{\mathrm{z}}\right)$

となることが, 式(5.3), (5.4)より得られる.

まずTEモードについて考える。ここではz方向に伝播す る波を考えているので, $z$ 方向の依存性を $\exp (-j \beta z)$ と置く ことができる。 $E_{y}$ は $x$ みの関数となるので, (5.7)式は次 のように全微分方程式で表される。

$$
\begin{aligned}
& \frac{d^{2}}{d x^{2}} E_{y}+\left(k^{2}-\beta^{2}\right) E_{y}=0, \quad k^{2}=\omega^{2} \mu_{0} \varepsilon \\
& H_{x}=-\frac{\beta}{\omega \mu_{0}} E_{y}, H_{z}=-\frac{1}{j \omega \mu_{0}} \frac{d E_{y}}{d x}
\end{aligned}
$$

$\varepsilon=\varepsilon_{0} n^{2} \sin \theta$ と置くと, $(5.8 \mathrm{a})$ は

$$
\begin{aligned}
& \frac{d^{2}}{d x^{2}} E_{y}+\left(k_{0}{ }^{2} n^{2}-\beta^{2}\right) E_{y}=0 \\
& k^{2}=k_{0}{ }^{2} n^{2}, \quad k_{0}{ }^{2}=\omega^{2} \mu_{0} \varepsilon
\end{aligned}
$$

$\beta$ は $z$ 方向に伝わる光波の伝播定数であり, 次式で与えられ る.

$$
\beta=k_{0} n_{1} \sin \theta=k_{0} N, N=n_{1} \sin \theta
$$

Nは導波モードが感じる屈折率で, 導波路の実効屈折率と 呼ばれる。

$x= \pm d / 2$ で電界と磁界が連続であり, $x= \pm \infty て ゙$ 発散しな い解を選んで(5.9)を解くと, 次式の解が得られる.

$$
\begin{aligned}
E_{y}= & E_{c} \cos (\kappa x+\phi) \quad|x| \leq d / 2 \\
E_{y}= & E_{c} \cos (\kappa d / 2+\phi) \exp \{-\gamma(|x|-d / 2)\} \\
& |x|>d / 2 \\
\kappa \frac{d}{2} & =m \frac{\pi}{2}+\tan ^{-1} \frac{\gamma}{\kappa}
\end{aligned}
$$

$m$ は 0 まは正の整数であり,横モードの次数である。 $\kappa, \gamma$ は次式で与えられる。

$$
\kappa^{2}=k_{0}{ }^{2} n_{1}{ }^{2}-\beta^{2}
$$

$$
\gamma^{2}=\beta^{2}-k_{0}{ }^{2} n_{2}^{2}
$$

光がコア内に閉じ込められて伝播できる条件は, (5.11a), (5.11b)を導いたように, 活性層内では振動解, クラッド層 では減衰解であるため, $\kappa, \gamma$ 実数である。このため, 伝播 定数 $\beta$ は次式で決まる範囲に制限される.

$$
k_{0} n_{1}>\beta>k_{0} n_{2}
$$

一例として, $\mathrm{Al}_{0.3} \mathrm{Ga}_{0.7} \mathrm{As}$ をクラッド層, $\mathrm{GaAs}$ をコ層とす るダブルへテロ構造導波路をとりあげる. $\mathrm{GaAs}$ のバンド ギャップエネルギー $1.41 \mathrm{eV}(\lambda=0.88 \mu \mathrm{m})$ に対応する屈折率 はFig.5.5より GaAsでは3.6, $\mathrm{Al}_{0.3} \mathrm{Ga}_{0.7} \mathrm{As}$ では3.4である。 $\mathrm{GaAs}$ 層の厚さ $d=1 \mu \mathrm{m}$ とすると, (5.11a), (5.11b)を解いて 図示(Fig.5.6)すると,0次, 1次, 2次の横モードが存在し得 ることが分かる。

\section{2 .2 単一モードの条件と光閉じ込め率}

次に0次の基本横モードのみが存在する単一モードの条 件を導く．一般化するため, 規格化周波数と規格化伝播定 数を導入する。( $5.12 \mathrm{a}),(5.12 \mathrm{~b})$ より，

$$
\kappa^{2}+\gamma^{2}=k_{0}{ }^{2}\left(n_{1}{ }^{2}-n_{2}{ }^{2}\right)
$$

この式にコアの厚さ半分 $d / 2$ の乗を乗じて, 無単位化する と,

$$
(\kappa d / 2)^{2}+(\gamma d / 2)^{2}=V^{2}, V=k_{2} n_{2} d / 2 \sqrt{2 \Delta}
$$

となる。 $\Delta$ は比屈折率差であり, 次式で表される.

$$
\Delta=\frac{\left(n_{1}-n_{2}\right)}{n_{1}}
$$

このVパラメーターは規格化周波数と呼ばれる．規格化伝 播定数bは次式で定義される.

$$
b=\frac{\beta^{2}-\left(k_{0} n_{2}\right)^{2}}{\left(k_{0} n_{1}\right)^{2}-\left(k_{0} n_{2}\right)^{2}}=\frac{\beta / k_{0}-n_{2}}{n_{1}-n_{2}}
$$

したがって, $V$ との間には次式の関係がある.

$$
V=\frac{1}{\sqrt{1-b}}\left[\tan ^{-1} \sqrt{\frac{b}{1-b}}+m \frac{\pi}{2}\right], m=0,1,2,3, \ldots
$$

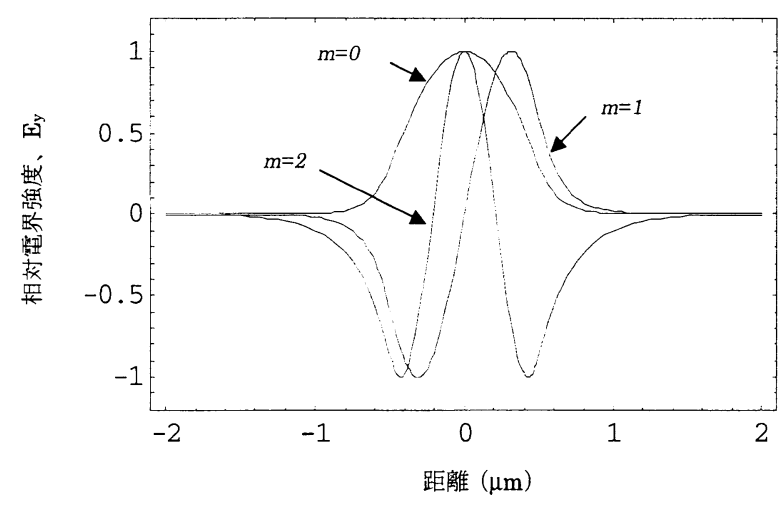

Fig.5.6 Allowed transverse modes for $\mathrm{AlGaAs} / \mathrm{GaAs} /$ $\mathrm{AlGaAs}$ waveguide. 
同様にTM波の場合は, 次式が得られる.

$$
\begin{aligned}
& V=\frac{1}{\sqrt{1-b}}\left[\tan ^{-1}\left(\frac{n_{1}}{n_{2}}\right)^{2} \sqrt{\frac{b}{1-b}}+m \frac{\pi}{2}\right], \\
& m=0,1,2,3, \ldots \ldots .
\end{aligned}
$$

単一モードの条件は, $m=1$ 以上のモードが存在しないこと であり,(5.18),(5.19)より，

$$
V<\pi / 2
$$

となる。この式を(5.15) 式に代入し, 単一モードとなるコ ア層の厚さ $d_{\max }$ であらわすと,

$$
d<d_{\max }=\frac{\pi}{k_{0} n_{1} \sqrt{2 \Delta}}=\frac{\lambda_{0}}{2 n_{1}} \frac{1}{\sqrt{2 \Delta}}
$$

これは, 媒質の材料の観点から, コアで発生する光の波長 が長く(バンドギャップエネルギーが小さく), 屈折率が小 さいほど, 導波路を作製する観点から, 比屈折率差が小さ いほど， $d_{\max }$ は大きくなることを示している．先に挙げた $\mathrm{Al}_{0.3} \mathrm{Ga}_{0.7} \mathrm{As} / \mathrm{GaAs} / \mathrm{Al}_{0.3} \mathrm{Ga}_{07} \mathrm{As}$ ダブルヘテロ構造導波路では $d_{\max }=0.36 \mu \mathrm{m}$ となる.

光導波路のコア領域に光が閉じ込められる割合を光閉 じ込め率と言う。これを「で表すと, TEモードでは

$$
\Gamma=\frac{\int_{-d / 2}^{d / 2}\left|E_{y}\right|^{2} d x}{\int_{-\infty}^{\infty}\left|E_{y}\right|^{2} d x}=\frac{V+\sqrt{b}}{V+1 / \sqrt{b}}
$$

と表される．「は活性層厚が大きいと1に近づくが,小さく なると活性層厚 $d に$ 比例して減少する. 「とdとの関係につ いては次回に述べる量子井戸レーザーに関連させて論じ る予定である。

\section{2 .3 単一横モードレーザーの基本構造}

ダブルへテロ接合レーザーでは, キャリヤを閉じ込めて しきい電流を小さくするため,バンドギャップエネルギー の差を大きくする.これに伴い, 屈折率差が大きくなり, 式 (5.21)より分かるように, 基本横モードで発振するコア層 の厚さが通常の半導体レーザーでは〜0.5 $\mu \mathrm{m}$ 以下に制限さ れる。しかしながら, ダブルヘテロ構造を基板上に, 順次, 薄膜層を平行に積層するため, LPEによってさえも基本横 モードで発振できる薄い活性層の形成は容易である.

これに対して,へテロ接合と平行な方向の横モードの成 分が単一となるためには, 例えばへテロ構造を導入して埋 め込み型のストライプ構造にして屈折率差を大きくする と, 活性領域の幅, すなわち, ストライプ幅を $1 \mu \mathrm{m}$ 以下にす る必要がある。このような幅の狭いストライプの作製に は, 電子ビームリソグラフィーや関連するエッチング技術 など微細加工技術の進歩を待つ必要があった。

一方, 高出力化の観点からは, ストライプの幅をできる だけ広げたいので, 屈折率差を小さくする必要がある。こ の観点から, 単一のストライプの場合は通常〜 $3 \mu \mathrm{m}$ 以下に 制限される. 半導体レーザーの光導波路はFig.5.7(a)に示 す利得導波路とFig.5.7 (b) (d) に示す屈折率導波路が基
本である。なお, 活性層以外の領域へ無駄なキャリヤが注 入されて動作電流の上昇を起こさないように, 電流狭窄構 造の作製も同時に行わなければならない. 電流狭窄構造 は, 高抵抗層, 逆バイアスpn接合などを活性層の両側に埋 め込むなどの複雑な構造の作製技術が必要であり,低電流 動作に不可欠である。

(1) 利得導波型

利得導波路はへテロ接合と平行な方向には作り付けの 屈折率分布は存在しないので, キャリヤが注入されていな い状態では屈折率は活性層内で一定である。キャリヤが 注入されると, その広がりにより, 屈折率分布を生じる。 屈折率と吸収(利得) 係数はクラーマス・クレーニヒの式で 関係している。吸収(利得) 係数の波長または光子エネル ギー依存性を知ることができれば屈折率の波長または光 子エネルギー依存性を知ることができる25)。この場合へ テロ接合と平行な方向 ( $y$ 方向)の活性層の誘電率 $\varepsilon_{1}$ は複素 数となる。キャリヤ注入などにより自由キャリヤが存在 すると, 光波が $\exp (-j \beta z)$ で变化する場合, 伝播定数 $\beta$ は複素 数となり, $\beta=\beta_{\mathrm{r}}+\mathrm{j} \beta_{i}$ と表される。 $\beta_{i}>0$ の場合は減衰する が, $\beta_{i}<0$ の場合は光の増幅が起こる. $\beta_{i}$ は吸収係数 $\alpha$ た は利得 $g$ と次の関係がある ${ }^{8)}$.

$$
\beta_{i}=\frac{\alpha}{2}=-\frac{\mathrm{g}}{2}
$$

$\alpha=-g<0$, すなわち, 誘導放出利得係数 $\mathrm{g}$ が正になれば増幅 され, 導波される。

この利得導波型では, 活性層と垂直方向ではダブルへテ 口構造による導波効果が強いので波面は平坦になるが, 水 平方向では波面は外から見ると凸になっているので, 焦点 がレーザーの内部にあるように見える。このため,出力光 に非点収差を生じる。ヘテロ接合と平行な方向では屈折 率導波でないため回折が大きい.このため共振器内に留 まる光子の寿命が短くなり縦モードが多重となり易い. このため, 温度変化によってバンドギャップエネルギーや 屈折率の温度変化により, 縦モードが入れ替わるときに生 じるモード競合雑音が軽減される。

(2) 屈折率導波型

半導体レーザーの横モードの単一モード化は, 電流に よって変化しない出射ビームの安定化, 変調特性の改善, 低 しきい值化に重要な課題として発展してきた. Fig.5.7(b) 〜 (d) は屈折率導波路による単一モード光導波路基本構造 の種類を分類したものである.

Fig.5.7 (b) は不純物濃度分布によるキャリヤ密度分布を 変化させ,屈折率導波路を形成するものである。これは自 由キャリヤ吸収(プラズマ吸収)による屈折率の変化を用い るものである. 屈折率の変化 $\Delta n_{e q}$ はキャリヤ密度の差 $\Delta n に$ 比例して減少し, 次式で与えられる.

$$
\Delta n_{e q}=-\frac{q^{2}}{2 \omega^{2} n_{e q} \varepsilon_{0} m_{r}} \Delta n
$$

$m_{\mathrm{r}}$ は換算質量, $n_{e q}$ は屈折率である。この例に $\mathrm{p}^{+} \mathrm{pn}$ 構造を用 いたTJSレーザーがある19,20)。ストライプ幅はp領域の幅 で決まる． $\mathrm{p}^{+} \mathrm{pn}$ 構造では中央の $\mathrm{p}^{+}$- $\mathrm{p}$ 間と $\mathrm{p}-\mathrm{n}$ 間のキャリヤ 密度の差を $\Delta n \sim(3-5) \times 10^{18} \mathrm{~cm}^{-3}$ とすると, $\Delta n_{e q} \sim 0.002$ とな 
り, 式(5.21)より基本横モードの幅は〜 $3 \mu \mathrm{m}$ 以下である.

Fig.5.7(c)は等価屈折率導波路型と言われる. ストライ プ領域の上または下の部分のクラッド層厚をその外部よ り厚くして,ヘテロ接合と垂直な方向の光閉じ込め率をス トライプ部の両側で小さくする。この結果, ヘテロ接合の 平行な方向ではストライプ部ではその外部より屈折率が 等価的に大きくなる。 ストライプの下の部分を基板側で 厚くしたCSPレーザーは, クラッド層厚をストライプ外部 の活性層の下で薄くして, 光電界が屈折率の大きいGaAs基 板に広がるようにして, 活性層の光閉じ込め率を低くして いる。このレーザー構造では, 基本横モードに比べ広がる 高次の横モードを吸収の大きいストライプ外部で抑制で きるため, 実質的に基本横モードの幅を広げることができ る。このCSPレーザーにより,TJSレーザーに引き続き, 定 常状態では単一波長で発振することが1976年に確かめら れた24).この構造はその後の光ディスク用光源の基本構 造となった。リッジ型といわれる表面のストライプ部が その外部より厚い構造では, ストライプ外部のクラッド層 の厚さが薄く, 空気とクラッド層の間の屈折率差が大き い.このため, 光電界は結晶内部に広がり, 活性層の光閉 じ込め率が下がるので,リッジストライプの部分で屈折率 が等価的に大きくなる，ストライプの幅を $2 \mu \mathrm{m}$ 以下にする 必要があるが, 最近になって電子ビームリソグラフィー技 術やエッチング技術による微細加工技術の進歩により, 容 易に作製できるようになった。この構造はエピタキシャ ル成長が一回で済むことは低価格化で有利である。

Fig.5.7 (d) は埋め込みへテロ $(\mathrm{BH})$ 構造としてAlGaAs/ GaAsdaダブルヘテロ構造に試みられた ${ }^{25)}$. 現在の光通信 用光源の基本構造として広く用いられている. あらかじ め成長しておいたダブルヘテロ構造ウェハをエッチングに よりメサ上のストライプを形成し, 2 回目の結晶成長によっ て屈折率が小さくバンドギャップの大きい半導体で側面 を埋め込む。この構造では屈折率差が大きいため, ストラ

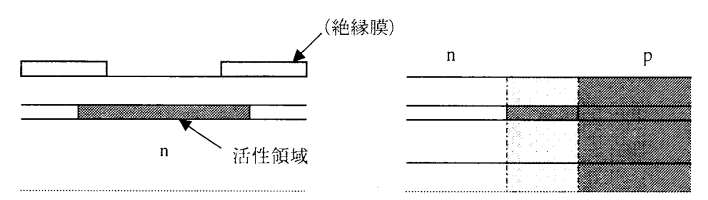
(a) 利得㾍波路 (フレーーナスライ

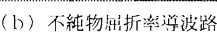
(TJS)

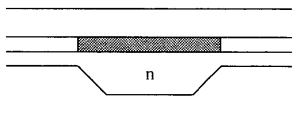

$\operatorname{CSP}$

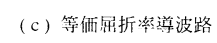

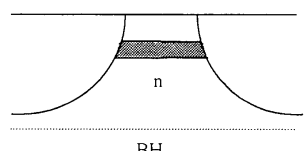

$\mathrm{BH}$

(d) 埋め込みへテロ構造

Fig.5.7 Basic structures for fundamental transverse mode semiconductor lasers.

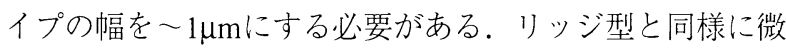
細加工技術の進歩により作製が容易になりつつある。

\section{3 縦モード制御と動的単一モード}

5.3.1 回折格子を用いた光導波路 (ブラッグ導波路) 半導体レーザーの応用分野の中で, 光ファイバ通信が最も 重要な分野の一つである. 石英ファイバを用いる通常の 光通信では, 損失は $1.55 \mu \mathrm{m}$ で最小となり, 伝送損失は理論 限界の $0.2 \mathrm{~dB} / \mathrm{km}$ まで低減されている。高速変調時に多 波長で発振するファブリー・ペロー型に代わり, 単一波長 で発振する動的単一モード (Dynamic Single Mode: 以下 DSMと略す)レーザーが開発されてきた22).

半導体レーザーのサイズは,一般に波長に比べてかなり 長い(数百倍〜数千倍)ので, 4.1で述べたように,多くの共 振モードが存在する。その中で,レーザー利得が最大にな る波長付近の幾つかの縦モードは,ほぼ同じ利得を受ける ので, 同時に発振する場合が多い.とくに, 高速変調時に おいては,キャリヤ密度が過渡現象により大きく変動する ため,顕著な多モード発振となる。高速変調時に縦モード が単一モード(単一波長)動作を維持できるためには, レー ザーの共振器長を極端に短くして, 共振モード間の利得の 差を大きくするか, あるいは一つの共振モードの共振器損 失を選択的に小さくすることが考えられる．前者は最近 注目されている面発光レーザーで実現されており, 次回に 述べる予定である。

Fig.5.8は利得曲線発振, しきい值利得 $g_{t h}$ と光強度 $S_{0}, S_{1}$, $\mathrm{S}_{2}, \cdots の$ 共振モード $\lambda_{\mathrm{I}}$ の関係を模式的に示したものであ る。最もしきい值の小さい $\lambda_{0} を$ 主モード, その他を副モー ドと呼ぶ. DSM動作の目安となる光強度比 $S_{1} / S_{0}$ は主モー ドと副モードの発振しきい值利得差 $\Delta g_{t h}$ で決まる.

一つの共振モードの共振器損失を選択的に小さくする ために, 波長選択性の強いブラッグ導波路が用いられる. 半導体レーザーに用いられるブラッグ導波路をFig.5.9に示 す。これらは等価屈折率 $n_{e q}$ が $n_{e q 0}$ を中心に, 周期 $\Lambda て ゙$ 光の進 行方向である $z$ 方向に周期的に变化した回折格子を形成し ている. Fig.5.9(a)は $n_{e q}$ が

$$
\begin{gathered}
n_{e q}=n_{e q 0}+\Delta n_{0} \cos \left(2 \beta_{0} z+\Omega\right), \\
\beta_{0}=2 \pi n_{e q} / \lambda_{B}=m \pi / \Lambda
\end{gathered}
$$

で表される. $\lambda_{B}$ は真空中のブラッグ波長, $m$ は回折格子の 次数である. $\Omega$ は $z=0$ に扔ける屈折率変化の位相で, 対称 構造では $\Omega=0$ である。

Fig.5.9(b)は位相シフト型ブラッグ導波路と呼ばれ, 屈折 率変化の位相を中央で右半分と左半分でシフトさせてい る。等価屈折率 $n_{e q}$ が $n_{e q 0}$ を中心, 左半分 $z<0$, 右半分 $z \geq 0$ で,それぞれ，

$$
\begin{aligned}
& n_{e q}=n_{e q 0}+\Delta n_{0} \cos \left(2 \beta_{0} z+\Omega\right), \quad z<0 \\
& n_{e q}=n_{e q 0}+\Delta n_{0} \cos \left(2 \beta_{0} z-\Omega\right), \quad z \geq 0
\end{aligned}
$$

ブラッグ導波路の解析はKogelnikによる結合波近似理論 で取り扱われる26)。ここではその要点を述べる。活性領 域内の電磁界を右へ進む進行波成分 $R(z)$ と左へ進む逆行 
波成分 $S(z)$ の重ね合わせとすると, ブラッグ波長付近の光 波については, 次式が近似的に成り立つ.

$$
\begin{aligned}
& -\frac{\partial R}{\partial z}+\left(\alpha_{E}-\delta \beta\right) R=j \kappa_{c} \exp (-j \Omega) \cdot S \\
& \frac{\partial S}{\partial z}+\left(\alpha_{E}-\delta \beta\right) S=j \kappa_{c} \exp (j \Omega) \cdot R
\end{aligned}
$$

ここで $\kappa_{\mathrm{c}}=\pi \Omega \Delta n_{e q} \lambda_{\mathrm{B}}$ は結合係数, $\alpha_{E}$ は電界に対する利得ま たは損失, $\delta \beta=\beta-\beta_{0}$ は伝播定数のブラッグ波長に対する伝 播定数との差である. 結合方程式の一般解は次のように 表される。

$$
\begin{aligned}
& R(z)=r_{1} \exp (\zeta z)+r_{2} \exp (-\zeta z) \\
& S(z)=s_{1} \exp (\zeta z)+s_{2} \exp (-\zeta z) \\
& \zeta=\sqrt{\kappa_{c}{ }^{2}+\left(\alpha_{E}-j \delta \beta\right)^{2}}
\end{aligned}
$$

これらの式により, 適当な境界条件を設定してR $(z)$ とS (z)を具体的に求めることができる.

Fig.5.9(a)には $\delta \beta=0$ (ブラッグ波長) $\delta \beta=\sqrt{(\pi / L)^{2}+\kappa_{c}{ }^{2}}$ に対する電力分布, $|R(z)|^{2}$ と $|S(z)|^{2}$ を示す. $\alpha_{E}=0$ と仮定し ている. $|\delta \beta|>\kappa_{c}$ の領域ではらは実数であり, 入射光は指数 関数的に減少することから,この領域をストップバンドと 称する. 逆に, $|\delta \beta|>\kappa_{c}$ の領域ではとは虚数であり, 正弦波 状の分布となる。この領域はパスバンドと呼ばれる。

$\delta \beta=\sqrt{(\pi / L)^{2}+\kappa_{c}^{2}}$ の場合は $\left|R_{0}\right|^{2}$ がそのまま右端から損失 なしで透過する.すなわち, ブラッグ導波路はブラッグ波 $(\delta \beta=0)$ 近傍では強い反射特性を示し, やや離れた波長で バンドパスフィルタ的な透過特性を示す.

Fig5.9 (b) にはブラッグ波長 $(\delta \beta=0)$ における透過および 反射の電力分布を示し, この場合の $\lambda / 4$ シフト導波路ではブ

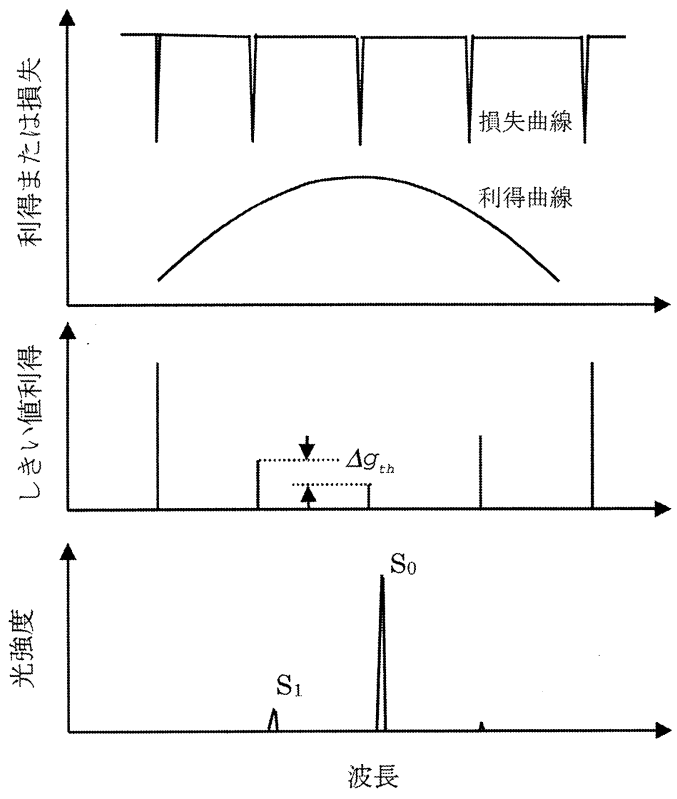

Fig.5.8 Gain, threshold gain, mode intensities above threshold vs. resonant mode (wavelength).
ラッグ波長で損失のない透過が起こる．以上に述べたよ うに, $\Omega=0$ の均一な回折格子の場合は最も強い反射が起こ り, $\Omega=\pi / 2$ の $\lambda / 4$ シフト回折格子では全く反射が起こらな い.このようなブラッグ導波路の特性を波長選択性の大 きいレーザー共振器に利用することができる.

\subsubsection{DFBおよびDBRレーザー}

ブラッグ導波路を用いたレーザーには, それ自体が共振 器として作用すると同時に利得を有する分布帰還型 (Distributed Feedback; 以下DFBと略す)レーザー24) と, 反射 器として用いる分布反射型 (Distributed Bragg Reflector; 以 下DBRと略す)レーザー27)に分けられる．動的単一モード レーザーとしては, とくに入シフト回折格子を用いたもの が重要である28).

まず,DFBレーザーを取り扱う。中央を原点 $z=0$ とし, 回 折格子の両端を $z= \pm L / 2$ とし反射がない場合について考え る. 振幅 $R_{0}$ の光が左端 $z=-L / 2$ に入射され, 右端 $z=L / 2$ か ら出力される一般的な位相シフト型のブラッグ導波路の 透過特性は次式で与えられる。

$$
\begin{aligned}
\frac{R(L / 2)}{R_{0}}= & \frac{4\left\{\kappa_{c}{ }^{2}+\left(\alpha_{E}-j \delta \beta\right)^{2}\right\} e^{-j \Omega}}{D} \\
D=\{(\zeta+ & \left.\left.\alpha_{E}-j \delta \beta\right) e^{-\zeta L / 2}-\left(-\zeta+\alpha_{E}-j \delta \beta\right) e^{\zeta L / 2}\right\}^{2} \\
& +\kappa_{c}{ }^{2} e^{-j 2 \Omega}\left\{e^{-\zeta L / 2}-e^{\zeta L / 2}\right\}^{2}
\end{aligned}
$$

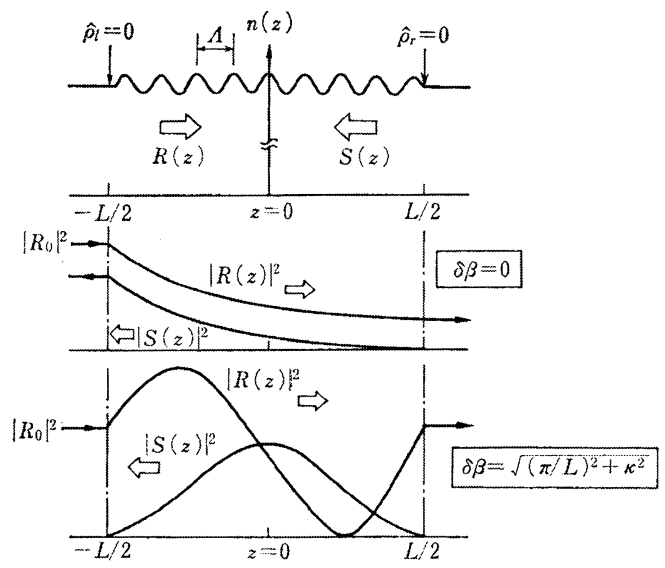

(a) 均一回折格子 $(\Omega \cdot 0)$

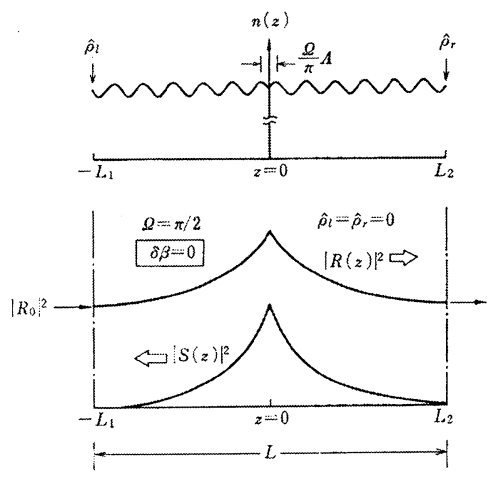

(b) $1 / 4$ シフト回折格子 $(\Omega=\pi / 2)$

Fig.5.9 Phase shift type Bragg wave-guide. 
DFBレーザーの発振条件は分母 $D=0$ のときに得られ る. Fig.5.10は電力透過率 $\left|R(L / 2) / R_{0}\right|^{2}$ を均一な回折格子 $(\Omega=0)$ と, $\lambda / 4$ シフト回折格子 $(\Omega=\pi / 2)$ について示したも のである. 利得 $\alpha_{E}$ が大きくなるにつれて, $\Omega=0$ の場合はブ

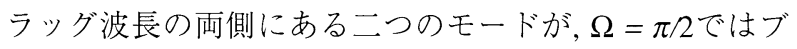
ラッグ波長のモードが強くなり, $\alpha_{E}$ が発振し，きい值利得 $\alpha_{\mathrm{th}}$ になると無限大に達する。 さらに $\alpha_{E}$ をきくしていくと， 次にしきい值の低いモードが無限大に達する。

位相シフト型DFBレーザーでは $\lambda / 4$ シフト,すなわち $\Omega=$ $\pi / 2$ ののがしきい值が最小となる. $\mathrm{L}=500 \mu \mathrm{m}$ の場合最小 のしきい值利得は $\alpha_{t h 0}=14 \mathrm{~cm}^{-1}$, 次の発振利得は $\alpha_{t h 1}=29$ $\mathrm{cm}^{-1}$ となる.この利得差は $\Delta \alpha_{t h}=15 \mathrm{~cm}^{-1}$ となり, 電力利得 差はこの2倍の $\Delta g_{t h}=30 \mathrm{~cm}^{-1}$ となる．このレーザーではス トップバンドの中心であるブラッグ波長が選択的に増幅 され発振に到る。

Fig.5.11に入/4シフトDFBレーザーの構造例を示す29!. DSM動作の目安となる光強度比 $1 \mathrm{~S}_{1} / \mathrm{S}_{0} 1$ は $35 \mathrm{~dB}$ 以上の優れた 特性が得られ, 高速変調時も安定な単一モード発振が維持 される28).

DBRレーザーは, ブラッグ導波路の反射特性を利用して いる. 回折格子反射器を受動光導波路に形成した分布反 射器を持つDBRレーザーは, 活性領域と共振器であるブ ラッグ導波路反射領域が空間的に分離しているために, 設 計上の自由度が大きい. このため, 変調器や光検出器など 各種の光導波路素子と集積する上で有利である.

さらに, DBRレーザーとDFBレーザーを発展させた分布 反射型レーザーが開発されている，入/4シフトレーザーで は安定単一波長動作を得るために共振器の中央付近に位 相整合 (位相シフト) 領域を設けるので, 光出力が前端面と 後端面から同じ割合で出射され, 前端面からの出射効率は 原理的に50\%以下となる。このレーザーは活性領域の結合 係数に比べて受動導波路領域の結合係数を大きくした深 い回折格子を用いる30).

これらのレーザーは, 電子ビームリソグラフィーやドラ イエッチングによる加工技術技術の進歩により, 低しきい 值, 高効率化が可能となっている.

本稿では動的単一モードレーザーについての足がかり 的な事項しか述べることはできないが, 詳しくは文献4)の 12章, 13章などを参照されたい.

\section{参考文献}

半導体レーザーに関する文献は莫大な数にのぼるので, 詳しくは前回に紹介した参考書1）～8)を参考にされたい. 本稿では半導体レーザーの発展の契機となったものをあ げる. 低電流動作のための電流狭窄構造, 各種ストライプ 構造の作製技術, 寿命などの実用化で重要な課題は, 半導 体レーザーのさらに詳しい理論的な取り扱いととものこ

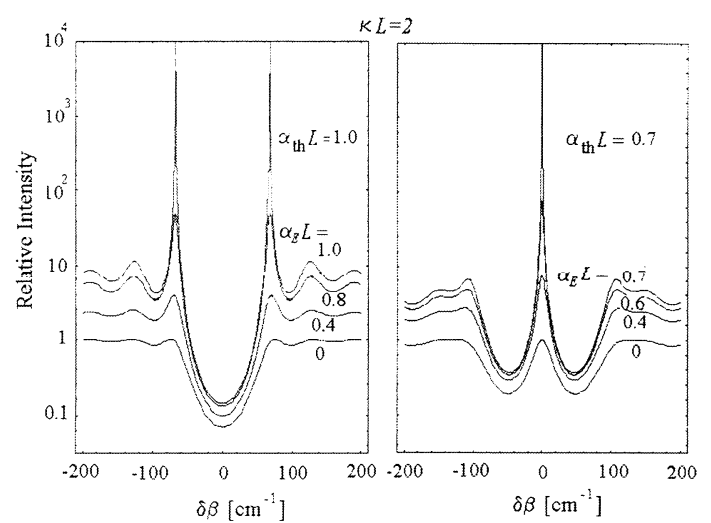

Fig.5.10 Power transmission rate $\left|R(L / 2) / R_{0}\right|^{2}$ vs. $\delta \beta=\beta-\beta_{0}$. The length of the waveguide $L$ is $500 \mu \mathrm{m}$, and reflection at $Z= \pm L / 2$ is negligible.

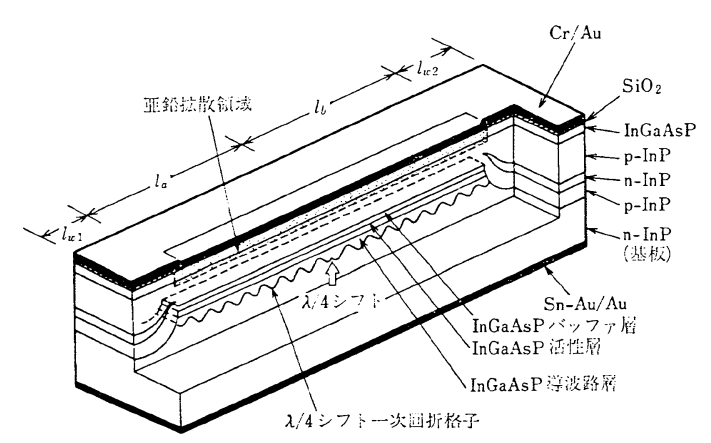

Fig.5.11 An example of InGaAsP/InP $\lambda$ shift DFB laser structure.

れらの参考書を参考にされたい。

17) J. C. Dyment: Appl. Phys. Lett. 10 (1967) 84.

18) H. Yonezu, I. Sakuma, K. Kobayashi, T. Kamejima, M. Ueno, and Y. Nannichi: Jpn. J. Appl. Phys. 12 (1973) 1585.

19) H. Namizaki, H. Kan, M. Ishii, and A. Ito: J. Appl. Phys. 45 (1974) 2785.

20) W. Susaki, T. Tanaka, H. Kan, and M. Ishii: IEEE J. Quantum Electron. QE-13 (1977) 587.

21) K. Aiki, M. Nakamura, J. Umeda, A. Yariv, A. Katzir, and H. W. Yen: Appl. Phys. Lett. QE-12 (1976) 145.

22) Y. Suematsu: Proc. IEEE 71 (1989) 692.

23) D. D. Sell, H. C. Casey, Jr., and K. W. Wecht: J. Appl. Phys. 24 (1974) 2650.

24) K. Aiki, M. Nakamura, T. Kuroda, and J. Umeda: Appl. Phys. Lett. 30 (1977) 649.

25) T. Tsukada: J. Appl. Phys. Lett. 45 (1974) 4899.

26) H. Kogelnik and C. V. Shank: J. Appl. Phys. 43 (1972) 2327.

27) W. Ng, H. W. Yen, A. Katzir, I Samid, and A. Yariv: Appl. Phys. Lett. 46 (1976) 684.

28) K. Utaka, S. Akiba, K. Sakai, and Y. Matsushima: Electron. Lett. 20 (1984) 326.

29) K. Utaka, S. Akiba, K. Sakai, and Y. Matsushima: Electron. Lett. 20 (1984) 1008.

30) K. Kohmori, S. Arai, Y. Suematsu, M. Aoki, and I. Aarima: Trans. IEICE (Journal of the Institute of Electronics, Information and Communication Engineers) E71 (1988) 318. 